Corporate governance in Germany:

Institutional background and empirical results

Ekkehart Boehmer

Arbeitspapier Nr. 78 


\title{
Corporate governance in Germany: Institutional background and empirical results
}

\author{
Ekkehart Boehmer ${ }^{1}$ \\ Humboldt University Berlin
}

March 24, 1999

\begin{abstract}
I survey empirical studies on German corporate governance and conclude that they raise intriguing questions for future research and have important political implications. First, current German transparency legislation ( $\mathrm{WpHG}$ ) is not adequate to achieve the objective of transparency as stated by the European Commission and the German Parliament. Compared to other developed economies, the German stock market is dominated by large shareholders. However, even after introducing the WpHG in 1995, the ultimately controlling parties are often not disclosed and transfers from smaller shareholders are legally possible. Second, due to proxy votes and board memberships, banks control a substantially higher fraction of voting rights than cash-flow claims. Moreover, banks extend more loan money to the typical firm than they hold as equity. Consequently, it is unclear whether their voting power is used in the interest of shareholders. Empirically, bank involvement appears to have a very limited effect on performance. Several open questions remain to assess the efficacy of the German model in relation to more market-based systems.
\end{abstract}

\footnotetext{
1 This study and related papers are available at http://www.wiwi.hu-berlin.de/ boehmer. I thank the German Science Foundation (DFG) for substantial financial support. The European Corporate Governance Network supported parts of this study. Theodor Baums, Marco Becht, Klaus Gugler, and Beatrice Kuehn were very helpful in discussing and commenting on various parts of this study. In addition, participants at the 1996 DFG Colloquium, the 1997 Workshop on Banking in Münster, the 1997 and 1998 ECGN Conferences in Milan, and the finance the University of Amsterdam provided helpful comments.
} 


\section{Introduction}

Corporate governance is currently a topic of great worldwide interest to academics, legislators, and practitioners. In addition to several academic articles, it has prompted active involvement of the OECD, the EU, the German Monopolkommission, the Bundestag, and several other institutions. ${ }^{1}$ Especially in comparison to the Anglo-American system, German corporate governance is characterized by lesser reliance on capital markets and outside investors, but a stronger reliance on large inside investors and financial institutions to achieve efficiency in the corporate sector. ${ }^{2}$ Since data on German corporations have become more easily available in recent years, the discussion has lately become more scientific and started to focus on studying the benefits and costs of the German system.

The empirical results presented in this survey focus on the relation between ownership structure and firm performance in Germany. I summarize several empirical studies on this topic and put them into context to the institutional and legal environment in Germany. Due to data restrictions on unlisted firms, most results are based on corporations trading in official markets, representing the first-tier stock market in Germany. These firms have to publish large blockholdings exceeding $25 \%$ in their annual report. While this type of ownership data has been accessible for several years, information on voting control has only become available with the 1995 transposition of the European Union's Transparency Directive into national law (Wertpapierhandelsgesetz, WpHG). ${ }^{3}$

Germany is characterized by a low stock-market capitalization relative to other developed economies. Prowse (1995) reports that market capitalization corresponds to $51 \%$ of GDP in the U.S., $90 \%$ in the UK, $71 \%$ in Japan, and only $29 \%$ in Germany. Adjusted for crossholdings, the figures are $48 \%$ in the U.S., $81 \%$ in the UK, $37 \%$ in Japan, and $14 \%$ in Germany. Using more recent data, Wenger and Kaserer (1997) estimate a relative capitalization of 21\% for Germany. Besides reducing true market capitalization, these substantial cross-holdings have implications for the governance of companies which are discussed below.

\footnotetext{
${ }^{1}$ Compare OECD Internal Documents SG/CG (98) 6 and SG/CG (98) 9 providing guidelines for corporate governance standards in member states, the EC Transparency Directive, the 1995 Gutachten to the Monopolkommission by Profs. Adam, Baums, and Wenger. The German legislators' involvement is evidenced, for example, by the second and third Finanzmarktförderungsgesetz and the KonTraG.

2 Monks and Minow (1995) provide a comprehensive introduction and description of corporate governance. See Kojima (1995) or Shleifer and Vishny (1997) for general surveys. Baums (1996a) and Charny (1999), for example, provide a discussion of potential convergence of the different systems. Zingales (1997) analyzes corporate governance in an environment of incomplete contracting. Mayer (1997) points out that differences in the various approaches to governance are mostly rooted in the varying structure of ownership and control across countries.

3 See Becht and Boehmer (1997) for an extensive review and analysis of Germany's implementation of the Transparency directive. We document several shortcomings of the implementation and show that several control relations are not revealed by current reporting procedures. Nevertheless, the required filings provide valuable data on voting control over officially listed corporations.
} 
This review is organized as follows. I first discuss descriptive statistics and some background information on ownership structure, voting control, and the identity of owners in section 2. Section 3 describes the disciplining mechanisms that can potentially sanction management. The extant empirical evidence on the relation between ownership structure and performance is discussed in section 4. The final section concludes and suggests open questions for future research.

\section{Ownership and control structures of listed corporations}

Germany is characterized by highly concentrated share ownership and substantial deviations from the one share - one vote paradigm. Among the different shareholder types, banks and insurance companies play an important role in controlling listed firms. In this section, I discuss the institutional background and descriptive statistics relating to the control over German corporations.

\subsection{Concentration of ownership}

Mella and Jähnke (1996) and several other papers report descriptive statistics on the concentration of ownership. For example, Franks and Mayer (1996, 1997) document that out of 171 large corporations, $85 \%$ have a shareholder owning more than $25 \%$, and $57 \%$ have a shareholder owning more than $50 \%$ of the equity. Boehmer (1999b) shows that these figures are representative for all listed firms over the period from 1985 to 1997 . He also finds that in 1996, 77\% of the median firms voting rights associated with officially traded shares are controlled by large shareholders (holding more than 5\%), corresponding to $47 \%$ of gross market capitalization (Boehmer 1999a).

\subsection{Ownership versus voting rights}

German law allows various devices that detach control rights from cash flow rights. First, shares may have limited but not multiple voting rights. Corporate law (Aktiengesetz, AktG) explicitly allows nonvoting shares up to the amount of ordinary shares outstanding. ${ }^{4}$ Non-voting shares are a potentially powerful mechanism to double the relative voting power of ordinary shares but are primarily used by relatively small, family-owned companies. Non-voting shares actually have a dormant voting right that is triggered by two consecutive omitted dividend payments. ${ }^{5}$ Since the securities law (Wertpapierhandelsgesetz, WpHG) does not require disclosing the ownership of non-voting shares, they can represent a potentially important pool of hidden voting power.

\footnotetext{
4 § 139 II AktG.

5 § 140 II AktG.
} 
In contrast, multiple voting rights per share are generally illegal but may be authorized by state authorities. ${ }^{6}$ Company statutes may further impose voting caps that limit the percentage of votes by individual shareholders. ${ }^{7}$ In practice, multiple voting rights are of little importance and limited to a few formerly state-owned firms. Voting caps are often claimed to reduce the power of large shareholders. It is not clear, however, how appropriately structured informal voting pacts to overcome the caps could be detected. Other important devices to leverage control are group structures involving cross shareholdings, contractual arrangements, personal interlockings of management and supervisory board members, and pyramids. Cross holdings effectively imply (potentially illegal $^{8}$ ) holdings of own shares and increase the voting power of any existing blockholder. ${ }^{9}$ In addition, they promote 'voting cartels' where involved management teams vote in favor of each other at the respective annual general meetings (AGMs). Contractual arrangements delegating control are widely used within German groups. Pyramids with outside equity on various levels may concentrate highly leveraged control at the top layer. ${ }^{10}$

Probably the most important source of voting rights deviating from ownership is the German proxy-voting system. $\S 135$ AktG governs how shareholders can name proxy agents as their representatives at the AGM. The proxy vote may be cast by any organization, bank, or other agent of the shareholder. The shareholder has the option to reveal his name, regardless of whether he provides explicit instructions how to vote his shares or not. Typically, shareholders remain anonymous, deposit their shares with banks, and grant general power of attorney to that bank with respect to all shares in their portfolio (see section 3.4 for a further discussion). Since disclosure of proxy votes is not legally mandated, they represent another important source of potentially hidden voting power. ${ }^{11}$

\subsection{Identity of ultimate blockholders}

Iber (1985) identifies foreign shareholders, the German government, and families as the most important German shareholders. His analysis is based on cash-flow ownership, because for his

\footnotetext{
6 § 12 AktG. Multiple voting rights are currently being phased out by most listed companies due to new legislation in 1998 (KonTraG).

7 § 134 I AktG. Voting caps are currently being phased out by most listed companies due to new legislation in 1998 (KonTraG).

$8 \S 71,71 \mathrm{~d}$ AktG.

${ }^{9}$ For empirical analyses of cross-shareholdings, see Prowse (1994) and Wenger and Kaserer (1997). For an analysis of personal interlockings, see Pfannschmidt (1995).

10 See Baums (1993), Adams (1994), or Wenger and Kaserer (1997) for sample cases and discussions.

11 Voting rights that have been exercised are publicly accessible at local company registers. There are several obstacles to assessing true voting power of bank: (1) exercised votes need not represent all voting rights available to the bank, (2) no centralized register or electronic access to the data exists, and (3) in many cases it takes months until documents are accessible, because the local registers are severely understaffed.
} 
sample periods (1963, 73, and 83) no voting data was available. Boehmer (1999a) analyzes firms reporting voting rights in excess of $5 \%$, which is mandatory since new legislation (WpHG) became effective in 1995. He shows that compared to other developed economies, the German stock market is dominated by large shareholders. Large blockholders control 77\% of the median firm's voting rights, corresponding to $47 \%$ of the market value of all firms listed in Germany's official markets. Banks, industrial firms, holdings, and insurance companies control about two thirds of this amount. Most importantly for outside investors, due to current legislation it is clear for neither group who exerts ultimate control over the shareholding firm itself. For the remaining blockholders, only blocks controlled by voting pools and individuals can be traced back to the highest level of ownership. Taken together, both groups control only $5.6 \%$ of all reported blocks. The German government controls $8 \%$, and it is not clear who ultimately is responsible for the consequences of decisions. Without knowing whose interests are represented using those voting rights, it is very difficult for outside investors to assess the incentives of large shareholders in the same firm to act in the interest of all shareholders.

Additional opaqueness results from 'control alliances' among the largest shareholders. For example, Boehmer (1999a) finds that the top five banks and the top three insurance companies are closely related through direct ownership and voting control. Jointly, these eight firms report control over $14 \%$ of all listed firms, or a market value of DM 147 billion considering only reported voting blocks. He argues that this figure substantially underestimates the true value under control of these blockholders. The reason is that large ownership links exist between the large shareholders that do not trigger legal reporting requirements. Consequently, joint majority control by business groups cannot be inferred from published data.

\subsection{Share ownership and control by financial institutions}

Baums and Fraune (1995) analyze AGM participation and voting for those 24 out of the top 100 listed firms that have more than $50 \%$ of their shares widely held. In 1992, about $58 \%$ of outstanding voting rights are present at the AGM. Out of the attending votes, banks control $13 \%$ due to own shareholdings, $10 \%$ due to dependent investment funds, and $61 \%$ due to proxy votes. Thus, Baums and Fraune find that banks control $84 \%$ of all attending votes while owning only about $7 \%$ of equity. The five largest banks alone control about $45 \%$ of attending votes, and additionally a majority in each other's AGMs. They further show that the resulting voting power is typically used to support management: while legally mandated items on the AGM agenda are approved with an average of about $99.8 \%$ of attending votes, only between $0.35 \%$ and $7.74 \%$ support items opposed by management. 
Supervisory-board composition has an additional influence on control leverage. Schroeder and Schrader (1998) find that in 1995 financial institutions hold 19\% of the seats of shareholder representatives on the boards of the top 100 German corporations. Even excluding mandates held by managers of other bank-controlled firms, this figure is about twice the percentage of equity owned by these institutions. Gorton and Schmid (1998b) find that bank representation on supervisory boards increases with their direct equity stake, but also with the fraction of proxy votes. Thus, due to proxy votes and board membership bank control over German corporations is substantially larger than it would be in a one share - one vote situation. ${ }^{12}$

\subsection{Transparency of ownership and control}

Becht and Boehmer (1999) analyze legal provisions relating to corporate transparency in Germany. Using disclosed ownership information, they show that despite the new securities trading law (WpHG) of 1995 the practical efficacy of disclosure regulation is very low. In several cases, ultimate ownership cannot be inferred from published filings. On the one hand, the formation of business groups involving less regulated legal forms as intermediate layers can systematically reduce transparency. On the other hand, the implementation of the law is not practical and not very effective. The paper illustrates the importance of additional reporting requirements for proxy voting by banks, voting control by investment funds, by firms not listed in an official market, and by business groups whose members jointly control a majority in each other. So far, neither needs to be reported to the public or, in the case of proxy votes, is not readily available.

\section{Limitations on the monitoring of management}

In the following sections, I discuss potential mechanisms to discipline management. Given the high concentration of ownership in Germany, blockholders and especially banks can potentially exert control over management, while the role of small shareholders is negligible. Analyzing the turnover of managing and supervisory boards, Franks and Mayer (1996), however, find no evidence that either banks or other blockholders act on behalf of other shareholders. While they document an active market in large blocks, they conclude that it cannot substitute for a market for corporate control as in the U.S. or the UK.

\footnotetext{
12 See also Albach and Kless (1982), who analyze personell interlockings among the 75 largest German firms for the years 1964 and 1978.
} 


\subsection{The market for corporate control}

Due to the concentrated ownership of shares, hostile takeovers are not possible without support by incumbent blockholders. While management can be bypassed (making an offer hostile), large shareholders and/or banks must generally be courted to support the bid for it to succeed. Since there are no immediate publication requirements for such negotiations, little is known about the consequences for the target firm. Some individual cases are illustrated by Peltzer (1989), Franks and Mayer (1996), and Jenkinson and Ljungqvist (1997). Especially the latter paper documents well the hostile character of several transactions, challenging the belief that hostile takeovers do not exist in Germany.

\subsection{Managerial remuneration}

Empirical analysis of the pay-performance relation is difficult in Germany because only aggregate but no individual compensation is disclosed. ${ }^{13}$ Furthermore, it is very common for managers of the parent firm to hold a seat on the supervisory boards of one or more subsidiaries. Since their compensation includes fractions of several aggregates, it is nearly impossible to calculate the total remuneration of the most important managers. Despite these difficulties, Schwalbach and Graßhoff (1997) analyze the relation between managerial pay and performance and find little evidence of a positive sensitivity. Schmid (1996b) obtains a marginally significant positive relation, and Knoll, Knoesel, and Probst (1997) find no sensitivity for the remuneration of supervisory board members. Thus, different samples and methodologies yield diverging estimates. Unfortunately, due to the data problems mentioned above, neither result can ultimately answer the question of how remuneration depends on performance. ${ }^{14}$

\subsection{Blockholders}

Large blockholders have incentives to maximize the value of their shares. Whether this involves maximizing firm value depends on the degree to which they can extract transfers from small shareholders. First, the typical German group includes several firms with outside equity and several without. Thus, it may be rational for large shareholders to transfer resources from subsidiaries with outside equity to other group units. Second, German law effectively allows sizeable transfers to blockholders once a coalition owns at least $75 \%$ of the votes. Specifically, a $75 \%$ majority may factually make a binding tender offer to minority shareholders below market

\footnotetext{
$13 \S 285$ IX HGB requires that the aggregate compensation of board members and management, respectively, is included in the annual report. Companies are exempt from this rule if publishing this information allows the public to identify compensation paid to a specific individual ( $\$ 286 \mathrm{IV} \mathrm{AktG)}$.
} 
value. ${ }^{15}$ The $75 \%$ majority need not even be held by one party, since two or more large blockholders may collude. Wenger, Hecker, and Knoesel (1996) analyze such offers to minority shareholders and find that in 39 of 53 cases the offer is below the market value on the day before, and in 32 cases below the market value three months earlier. For the former 39 cases, the market value on average exceeds the compensation to minority shareholders by $74 \%$. Additionally, blockholders may use crossholdings and pyramidal groups to transfer resources from subsidiaries with outside shareholders to units without. Therefore, a priori it is not clear that it is easier for blockholders to increase the value of their stake by acting on behalf of all shareholders, an issue clearly deserving future research efforts.

\subsection{Institutional investors}

The German pension system currently does not involve public funds but rather leaves pension contributions under control of either the government or the employer. Therefore, institutional investors consist primarily of banks, insurance firms, dependent investment funds, and foreign funds. Of these, banks play the most important role. They can exert control over corporations in several ways. The most obvious are direct ownership of shares, the provision of loans, by being represented on supervisory boards, and other business relations. Maybe most importantly, a further channel of substantial influence comes via proxy votes that small shareholders delegate to the banks administrating their stock portfolios. ${ }^{16}$ None of these channels taken individually constitutes an issue that would draw public attention like the ,power of banks " has in the recent years. Rather, the combination of power from the various sources is what deserves critical and thorough attention.

The capital representatives on German supervisory boards are legally supposed to represent shareholders, voice their concerns at annual general meetings (AGMs), and guard shareholders against value-decreasing actions by management. From this perspective, the important issue is how many board seats are filled with bank representatives and how many votes are controlled by banks relative to the shares directly owned by banks. Edwards and Fischer (1994) and Gerum et al. (1988) show that banks hold more seats than warranted by their shareholdings, and, in addition, the correlation between the number of bank seats and direct bank stakes is low. Since banks also control

\footnotetext{
14 In a related study, Kaplan (1994) finds no significant relation between bank control and board turnover for German corporations.

$15 \S \S 304,320 \mathrm{~b}$ AktG. See also Hecker and Wenger (1995) for a detailed discussion of potential transfers between large and small shareholders and Adams (1994) for the implications of cross-shareholdings in this regard. Bebchuck and Kahan (1999) model and discuss the problems arising in determining an appropriate consideration in such transactions.

16 For discussions of the German proxy-voting mechanism, see, for example, Köndgen (1994), Baums and Randow (1995) and Baums (1996b). For a comparison of different mechanisms in the EU member countries, see Baums (1997).
} 
most votes of small shareholders via the proxy system, the important question is whether the interests of banks coincide with those of shareholders.

Due to their information advantage, banks are potentially very effective monitors but will generally have little incentive to act on behalf of other shareholders. First, due to proxy votes and board memberships their control rights substantially exceed their interest in equity cash flow. Second, for the typical firm, the amount of debt held by banks exceeds the amount of equity held in the same firm by a factor greater than ten and much likely substantially larger. ${ }^{17} \mathrm{~A}$ third reason is additional fee-generating activity involving these firms. It is widely known that decisions maximizing the value of loans often reduce the market value of equity. The same argument holds for fee-maximizing decisions. Therefore, the objective of the banks should be to balance decisions increasing the value of debt versus those increasing the value of equity. Given the substantially larger size of the debt portfolio, it is rational, legal, and fully ethical for banks to act as debtors in all respects. ${ }^{18}$ The legally and politically sensitive issue is that board seats that do not mirror share ownership and proxy votes supposed to exclusively represent shareholders are used to achieve that goal. While this practice is legal and widespread, it would be in the interest of shareholders to prevent it and thereby increase firm value by assuring that voting rights are exercised in their own interests.

In this sense, the voting process is an essential element towards a shareholder-oriented AGMs and supervisory boards. ${ }^{19}$ It represents the major source of the potential mismatch between banks' cash flow risk and voting power and several proposals have been made to modify it. Köndgen (1994) suggests to professionalize the proxy agents and discusses incentive problems of various alternatives. Baums (1996) and Latham (1998) explicitly suggest different procedures for electing voting agents. Baums proposes new regulation that lets shareholders elect one or more representatives who exercise their voting rights. Latham, in contrast, proposes a market solution where professional firms compete for shareholders' voting rights.

\footnotetext{
17 No publicly available figures provide information on the precise composition of banks' interests in equity and debt to German listed corporations. A back-of-the-envelope calculation proceeds as follows. In 1996, the DAI reports that the equity-to-capital ratio of listed corporations is 39\% (DAI Fact Book 1996). Own calculations reveal that banks own about $8 \%$ of these firms' equity. Since German firms very rarely use public bonds, it is save to assume that most long-term debt consists of bank loans. Thus, the portfolio of a typical bank can be described as a function of the ratio of bank loans to total corporate liabilities. For example, if all corporate debt were from banks, the banks finance $8 \% * 39 \%=3.12 \%$ of listed firms' total assets in the form of equity shares, and $61 \%$ in the form of loans. Using the cautious assumption that corporate liabilities consist to only one third of bank loans, banks still finance about $20 \%$ of the corporations' total assets using loans. Therefore, for the typical bank the value of its loan portfolio to a typical listed corporation exceeds the equity interest in the same firm by a factor between 7 and 20. Economy-wide, Edwards and Fischer (1994) estimate that bank-supplied equity to non-banks is about $3 \%$ of bank-supplied loans to the same firms.

18 For the U. S., Payne, Millar, and Glezen (1996) document evidence consistent with the view that banks use their voting rights in the interest of management (as opposed to that of shareholders) when banks have debt or fee-related income associated with the firm.

19 Böhm (1992) obtains similar conclusions and suggests a voting procedure where the voting rights of absent small shareholders are granted to small shareholders present at the AGM (p. 211). See also Köndgen (1994) and Baums (1996b) for critical discussions.
} 
Furthermore, if maximizing the value of debt is the common goal of banks, disagreement across banks on the firm's optimal course of action is very unlikely. Therefore, the number of different banks casting votes at the AGM does not matter. The results in Baums and Fraune (1995) support this claim, because banks virtually always vote in favor of management proposals, independent of the number of banks involved. ${ }^{20}$

These arguments illustrate the importance of bank influence for affected firm. If banks can indeed exert influence over firms by voting at AGMs and by being represented on supervisory boards, their decisions are likely to affect firm value. If banks use their power to maximize debt value, their decisions will have a negative effect on the value of equity. Thus, the effectiveness of banks as actively monitoring shareholder representatives is ultimately an empirical question and is discussed in section 4.

\section{Ownership structure, bank control, and firm performance}

From the previous discussion, blockholders and banks are the main candidates for efficient and effective monitoring of management. Thus, the question is whether they use their power to act on behalf of other shareholders or to act in their own interest (transferring resources from other shareholders or maximizing the value of other financial interests in the firm). Due to the important public policy implications, most empirical studies analyze the relation between bank control and firm performance. ${ }^{21}$ Most studies take ownership structure as exogenous and model selected performance measures as a function of bank control, other ownership characteristics, and various control variables. Unfortunately, the results are inconsistent with each other and extremely sensitive to the sample, the period, and the methodology.

Specifically, only Cable (1985) and Gorton and Schmid (1998b) obtain evidence of a positive relation between bank control and performance. Cable (1985) finds a positive relation between a concentration measure of bank votes, bank representation on the supervisory board, and

\footnotetext{
20 While proponents of the current system claim that banks do represent shareholders, Köndgen (1994) points out an interesting inconsistency in this regard. When the German corporate code (AktG) was revised in 1965, legislators discussed a proposal that would prevent banks from proxy voting shares at their own AGMs. According to Zöllner (1973), it was rejected on the ground that then banks' AGMs would be dominated by their competitors. Therefore, legislators could not have been convinced that proxy votes represent shareholder interests and should have modified the proxy system in the first place.

21 Two papers analyze the effect of ownership concentration from a different angle. Weigand and Lehmann (1998) find a positive relation between ownership concentration and performance (ROA) if a family is the blockholder. Herrmann and Franke (1996) compare the performance of foundation-owned firms to that of other corporations. Although foundation-owned firms should exhibit the greatest agency problem, they find no significant differences in performance. They document some evidence, however, that foundation-owned firms act more in the interest of employees as opposed to equity holders. Gorton and Schmid (1998a) find that firms with legally mandated equal representation of workers and shareholders on the supervisory board have worse performance but lower risk than other firms. They further find that equal representation also results in greater pay-to-performance sensitivity of compensation to supervisory board members. Thus, it is not clear, whether equal employee representation is good or bad for shareholders.
} 
the ratio of bank loans to total debt on average performance between 1968 and 1972.22 The small sample of only 48 firms diminishes the explanatory power of the study. More problematic is using the ratio of equity income to total assets as a performance measure. As Chirinko and Elston (1996) point out, equity income is negatively related to leverage. They find that bank-influenced firms have lower leverage and conclude that Cable's performance measure is biased upwards.

Gorton and Schmid (1998b) find that bank ownership significantly increases the return on equity while proxy votes have no effect. When performance is measured by the market-to-book ratio of equity, the result is less pronounced. Their estimations are based on two sets of firms each in 1975 and 1986, both years with below-average GNP growth. Chirinko and Elston (1996) therefore suspect that the results may not be representative. Supporting this claim, Schmid (1996a) uses the same basic methodology as in Gorton and Schmid (1998b) but a sample from 1990. The author documents a U-shaped relation between direct bank ownership and return on equity. The fraction of bank ownership representing the minimum varies with concentration measures of all shareholders and banks, respectively. Schmid estimates that bank equity ownership has a negative relation to performance up to blocks between $15 \%$ and $45 \%$ depending on the concentration measures. Since this appears to apply to most firms in his sample, his results are at odds with those from Gorton and Schmid (1998b).

Seger (1997) obtains some evidence of a positive relation between direct bank ownership and several performance measures, but its significance depends strongly on the specification of the ownership variable. He obtains stronger result for firms where a banker chairs the supervisory board and the fraction of bank loans is high, both of which are negatively related to performance.

Chirinko and Elston (1996) find no discernible effect of equity held by banks and insurance companies on the cost of capital and on the average return on assets between 1965 and 1990. Perlitz and Seger (1994) find that firms under strong bank influence are less profitable (performance is measured using alternative ratios based on accounting profits and cash flows averaged from 1990 to 1993). However, when financially distressed firms are excluded from the sample, the negative relation between bank influence and profitability is no longer significant. The primary shortcoming of this study is that only a univariate two-sample comparison is used. Chirinko and Elston (1996) replicated the analysis in a multivariate regression framework and, using the same period did not obtain significant estimates. Nibler (1995) uses the same performance measure and a similar regression framework as did Cable (1985). For more recent data the author finds a positive relation

\footnotetext{
22 Cable (1985) gives little indication of his sampling period. He uses proxy-voting data from 1974, thus implying a relation to past performance.
} 
between direct bank ownership and average performance between 1988 and 1992, but a negative effect of bank proxy votes and the ratio of bank loans to total debt.

Except for Gorton and Schmid (1998b), who have employed market-to-book ratios in addition to other variables, all previous studies have used performance measures based on book values. While market returns should be a superior measure, their forward-looking nature leads to ambiguous inferences in such studies. For example, Wenger and Kaserer (1997) find a negative relation between holding-period market returns from 1973 to 1995 and bank ownership. While their interpretation is that bank ownership has caused lower returns, the causal relation could as well go the other way (and alter the conclusions substantially). For example, if banks tend to invest primarily in struggling firms that have lost market value over a couple of years, the estimated relationship between bank involvement and market returns would be negative. Contrary to their conclusions, however, such a causal relation would support a monitoring function performed by banks. A second problem with market returns is that in efficient markets returns should be affected only at the time of a change in bank influence, but not afterwards. Therefore, it is not clear what the negative relation estimated by Wenger and Kaserer (1997) means.

Using a different approach to analyze market returns, Boehmer (1999b) analyzes the effect of bank influence on the net present value of major investment decisions instead of estimating a cross-sectional regression. He finds that bank control does not imply better monitoring and that majority control by banks is detrimental to shareholders. However, large blockholders controlling less than 50\% appear to play an important monitoring role, especially if banks are involved. Specifically, bidders where banks potentially control a large fraction of the voting power via proxy votes clearly benefit from minority blockholders. Bank involvement will be beneficial if financial institutions control the second or third largest stake, but not if they control the largest stake. Therefore, it seems that only if there is a force independent of the bank that decision quality is going to be improved (in the sense of increasing shareholder wealth). Additionally, bidders whose groups include firms that are majority-controlled by financial institutions complete the most value-reducing takeovers. This result is not consistent with the presumption that German banks provide an efficient monitoring function to corporations and is robust with respect to various specifications of the test. Even if these acquisitions are part of an efficiency-enhancing restructuring program, bidder shareholders will lose wealth as a result. 


\section{$5 \quad$ Conclusions and open questions}

In Germany, large blockholders and banks control a substantial portion of exchange-listed firms. Blockholders naturally have incentives to act on behalf of shareholders. On the other hand, they are sufficiently powerful to divert resources from other shareholders to their own portfolio. To date, there is some evidence that implies such transfers and little evidence that blockholders positively affect firm value. Studies of this kind are scant because at least until 1995 there was little information published on the identity, activity, and transactions of blockholders. Future research on the incentives and behavior of large shareholders would clearly be beneficial.

Following the transposition of the EU Transparency Directive effective in 1995, AGs listed in an official German stock market must disclose parties controlling more than $5 \%$ of the voting rights. Since creditor protection is deeply rooted in German commercial law, the practical efficacy of disclosure regulation is still very low: the formation of groups involving less regulated legal forms as intermediate layers can substantially reduce transparency. Similarly, investment funds and banks face even less restrictive disclosure requirements. Voting rights deriving from proxy votes or fund ownership are generally exempt from the 5\% filings mandatory for other firms.

Due to proxy votes and board memberships, banks control a substantially higher fraction of voting rights than cash-flow claims. Moreover, banks extend more loan money to the typical firm than they hold as equity. Therefore, it is an empirical question whether the resulting voting power is used rationally to act as creditors or idealistically on behalf of shareholders. Previous empirical studies have produced conflicting evidence and many suffer from shortcomings relating to data and methodological issues.

\subsection{Concentration and transparency of control in Germany}

Compared to other developed economies, the German stock market is dominated by large shareholders. However, even after introducing the WpHG in 1995, the ultimately controlling parties are often not disclosed. This has important consequences for outside shareholders. First, an investor in a typical German corporation faces a majority of voting rights controlled by large shareholders. To the extent that expropriation in the form of wealth transfers to larger shareholders (when a blockholder has control) or to creditors (when proxy votes give majority control to banks) is possible, he will discount the value of shares to reflect his weak bargaining position. Put differently, an uninformed investor is likely to increase his required rate of return with increasing uncertainty about the incentives of large shareholders in the same firm. Therefore, the low transparency of control is likely to increase the cost of capital to affected German corporations relative to their 
international competitors listed in markets that are more transparent. Full disclosure of control would likely reduce uncertainty with respect to expropriation and increase the value of affected firms. To determine the cross-sectional value of transparency, in national or international settings, is an important question for future research.

\subsection{The relation between ownership structure and firm performance}

Several previous and concurrent studies analyze the relation between ownership structure (in particular focusing on bank control) and performance in Germany. The results depend strongly on sample, period, and methodology used. In sum, both highly concentrated ownership and substantial bank control per se apparently have only a modest cross-sectional effect on German corporations. A deeper analysis of these issues that incorporates more specific variables about the firms' industries and other characteristics would help to understand the real consequences of concentration and bank control.

In addition, most empirical efforts are rather ambiguous on the date of the employed ownership and bank-control data. Although it would be essential for a cross-sectional study, none of these rationalizes when and for how long bank control should affect performance. All implicitly assume that current performance depends on bank control in a close-by period, either before or after the period over which performance is measured (under the questionable assumption that control does not change over time). For example, probably due to the extremely high cost of reliable data, no study tests restrictions on the lead-lag relation between performance and bank control. Such tests could more than illuminate the actual efficacy of powerful banks and large shareholders and represent another fruitful area for future research.

\subsection{Policy implications and future research}

Empirical studies on German corporate governance raise intriguing questions for future research and have important political implications. First, current German transparency legislation $(\mathrm{WpHG})$ is not adequate to achieve the objective of transparency as stated by the European Commission and the German Parliament. Neither proxy voting by banks, voting control by investment funds or by firms not listed in an official market, nor by business groups whose members jointly control a majority in each other needs to be reported to the public (or, in the case of proxy votes, is not readily available).

Second, the involvement of financial institutions in the corporate sector has ambiguous effects on the affected companies' performance. Given that on average banks extend substantially more debt than equity to listed firms, they clearly have incentives to maximize the value of debt as 
opposed to that of equity. At least since Jensen and Meckling's (1976) analysis of agency problems, it is basic knowledge in financial economics that creditors and shareholders have distinctly different interests. Therefore, banks represent a priori poor candidates for representing shareholders at annual general meetings, especially when their voting rights come from proxy votes and not from direct shareholdings.

Empirically, bank involvement appears to have a very limited effect on performance. Since it has no discernible positive effect on listed firms empirically, it is hard to support the claim that the interests of small shareholders are well represented via the proxy-voting mechanism. The absence of an effect, however, is likely to mask important differences across different types of bank involvement. For example, a bank with a substantial equity stake and no outstanding loan to the same company is likely to act in the interest of shareholders. On the other hand, if a bank without equity ownership, but with substantial loan interests, controls a majority of (proxy) votes, it is unlikely that it acts irrationally and does not maximize the value of the firm's debt. Additionally, since the interest in debt maximization is common to most banks, they are likely to act in concert even without explicit agreements to this end. Due to the latent threat that shareholders' voting rights are used against them in this way, it is mandatory for legislators and the BAWe to assure that the type of bank control is publicly revealed. In particular, legal provisions should assure that direct share ownership by banks (which tends to increase the alignment of their interests with that of shareholders) and control via other means, such as supervisory board representation, proxy votes, and especially amount and type of lending are treated separately and fully disclosed if listed companies are affected.

To a similar extent, the argument above also applies to blockholders not affiliated with financial institutions. Without knowing who ultimately controls a corporation and without being able to infer his incentives to act in the interest of all shareholders, outside investors will require a higher rate of return. To alleviate their fear of expropriation, transparency is necessary to let uninformed investors make educated decisions about where to invest and whom to give authority over their voting rights.

Future research should address the relation between ownership structure and performance in more detail. For example, it is still not clear what the causal relation between bank control and performance is. Do blockholders and banks pick their control targets based on their performance and remain passive afterwards, or do they choose deliberately and then actively steer the firm? Both strategies would cause an empirical correlation between the control structure and performance in 
most previous studies. To disentangle the two, it is necessary to distinguish between past, concurrent, and subsequent ownership-induced performance changes.

Another intriguing question is why Germany has failed to implement full transparency with the WpHG, given the clear intentions to that end at the outset of discussions at the EU level. It is possible that true transparency is not beneficial to the German economic sector, as it has developed over the centuries. It is also possible that it has the potential to significantly reduce the cost of capital of German corporations, and consequently improve their competitive position in world markets. In my opinion, these issues have not received sufficient attention in the way of positive empirical research. One potential explanation for the current state of transparency legislation is that legislators have expected unreasonably high costs for firms affected by the legislation. In that case empirical research, for example comparative analyses of German firms and those in more transparent markets, could corroborate or alleviate those concerns. Another potential explanation is that benefactors of less transparency (i. e., creditors represented by financial institutions and large shareholders able to divert wealth from small shareholders) have had a sufficiently powerful lobby to prevent substantial deviations from the status quo. Also in the latter case, empirical research of a comparative nature could convince legislators to take measures that promote German capital markets and reduce the cost of capital to firms listed there, independent of potentially one-sided interest in either direction. 


\section{References}

Adams, M., 1994, Die Usurpation von Aktionärsbefugnissen mittels Ringverflechtung in der Die Aktiengesellschaft 39, 148-158

Albach, H. and H.-P. Kless, 1982, Personelle Verflechtungen bei deutschen Industrieaktiengesellschaften, Zeitschrift für Betriebswirtschaft 52, 959-977.

Baums, T. and C. Fraune, 1995, Institutionelle Anleger und Publikumsgesellschaft: Eine empirische Untersuchung, Die Aktiengesellschaft 40, 97-112.

Baums, T. und P. v. Randow, 1995, Der Markt für Stimmrechtsvertreter, Die Aktiengesellschaft 40, 145-163.

Baums, T., 1993, Corporate governance in Germany: System and recent developments, in: Isaksson, M. and R. Skog (eds.), Aspects of corporate governance, Juristförlaget, Stockholm, 31-54.

Baums, T., 1996a, Corporate governance systems in Europe: Differences and tendencies toward convergence, Working Paper, University of Osnabrueck.

Baums, T., 1996b, Vollmachtstimmrecht der Banken-Ja oder Nein?, Die Aktiengesellschaft 41, 1126.

Baums, T., 1997, Shareholder representation and proxy voting in the European Union: A comparative study, Working Paper, University of Osnabrück.

Bebchuk, L. A. and M. Kahan, 1999, The "lemons effect" in corporate freeze-outs, Discussion Paper No. 248, Harvard Law School.

Becht, M. and E. Boehmer, 1999, Transparency of ownership and control in Germany, Working paper, Humboldt-University Berlin.

Boehmer, 1999a, Who controls Germany? An empirical assessment, Working paper, HumboldtUniversity Berlin.

Boehmer, 1999b, Industry groups, large shareholders, and bank control: An analysis of German takeovers, Working paper, Humboldt-University Berlin.

Cable, J., 1985, Capital market information and industrial performance: The role of West German banks, Economic Journal 95, 118-132.

Charny, D., 1999, The German corporate governance system, Working Paper, Harvard Law School.

Chirinko, R. S. and J. A. Elston, 1996, Finance, control, and profitability: An evaluation of German bank influence, Working paper, WZB Berlin.

Edwards, J. and K. Fischer, 1994, Banks, finance, and investment in Germany, Cambridge University Press, Cambridge, UK.

Franks, J. and C. Mayer, 1996, Ownership, control, and the performance of German corporations, Working paper, London Business School.

Franks, J. R. and C. Mayer, 1997, Corporate ownership and control in the U.K., Germany, and France, in: Chew, D. H. (ed.), Studies in international corporate finance and governance systems, Oxford University Press, 281-296.

Gerum, E., H. Steinmann, and W. Fees, 1988, Der mitbestimmte Aufsichtsrat: Eine empirische Untersuchung, C. E. Poeschel Verlag, Stuttgart.

Gorton, G. and F. A. Schmid, 1998a, Corporate finance, control rights, and firm performance: A study of German codetermination, Working paper, University of Pennsylvania. 
Gorton, G. and F. A. Schmid, 1998b, Universal banking and the performance of German firms, Working paper, University of Pennsylvania.

Hecker, R. and E. Wenger, 1995, Der Schutz von Minderheiten im Vertragskonzern: Ein Betriebsunfall des Aktienrechts, Zeitschrift für Bankrecht und Bankwirtschaft 7, 321-424.

Herrmann, M. and G. Franke, 1996, The performance of foundation-owned firms in Germany, Working paper, University of Konstanz.

Jenkinson, T. and A. Ljungqvist, 1997, Hostile stakes and the role of banks in German corporate governance, Working paper, Oxford University.

Jensen, M. and W. Meckling, 1976, Theory of the firm: managerial behavior, agency costs and ownership structure, Journal of Financial Economics 3, 305-360.

Kaplan, S., 1994, Top executives, turnover, and firm performance in Germany, Journal of Law, Economics, and Organization 10, 142-159.

Knoll, L., J. Knoesel, and U. Probst, 1997, Aufsichtsratsvergütungen in Deutschland: Empirische Befunde, Zeitschrift für betriebswirtschaftliche Forschung 49, 236-253.

Köndgen, J., 1994, Duties of banks in voting their clients' stock, in: Baums, T., R. M. Buxbaum, and K. J. Hopt (eds.), Institutional investors and corporate governance, de Gruyter, 531-554.

Latham, M., 1999, The corporate monitoring firm, Corporate Governance - An International Review 7, forthcoming.

Mella, F. and R. Jähnke, 1996, Wem gehören die deutschen Aktiengesellschaften?, $12(18.01 .96), 6$.

Nibler, M., 1995, Bank control and corporate performance in Germany: The evidence, Working paper, Cambridge University.

Payne, T. H., J. A. Millar, and G. W. Glezen, 1996, Fiduciary responsibility and bank-firm relationships: An analysis of shareholder voting by banks, Journal of Corporate Finance 3, 75-87.

Peltzer, M., 1989, Hostile Takeovers in der Bundesrepublik Deutschland?, Zeitschrift für Wirtschaftsrecht 10, 69-79.

Perlitz, M. and F. Seger, 1994, The role of universal banks in German corporate governance, Business and the Contemporary World 6, 49-67.

Pfannschmidt, A., 1995, Mehrfachmandate in deutschen Unternehmen, Zeitschrift für Betriebswirtschaft 65, 177-203.

Prowse, S., 1995, Corporate governance in an international perspective: A survey of corporate control mechanisms among firms in the U. S., UK, Japan, and Germany, NYU Salomon Center 4, Blackwell Publishers, Cambridge, Massachusetts.

Schmid, F. A., 1996a, Beteiligungen deutscher Geschäftsbanken und corporate performance, Zeitschrift für Wirtschafts- und Sozialwissenschaften 116, 273-310.

Schmid, F. A., 1996b, Vorstandsbezüge, Aufsichtsratsvergütung und Aktionärsstruktur, Zeitschrift für Betriebswirtschaft 67, 69-83.

Schroeder, U. and A. Schrader, 1998, The changing role of banks and corporate governance in Germany: Evolution towards the market?, in: Black, S. W. and M Moersch (eds.), Competition and convergence in financial markets, Elsevier, 17-34. 
Schwalbach, J. and U. Graßhoff, 1997, Managervergütung und Unternehmenserfolg, Betriebswirtschaft 67, 203-217.

Seger, F., 1997, Banken, Erfolg und Finanzierung, Gabler Verlag, Wiesbaden.

Weigand, J. and E. Lehmann, 1998, Does the governed corporation perform better?, Working paper, University of Erlangen-Nürnberg.

Wenger, E., R. Hecker, and J. Knoesel, 1996, Abfindungsregeln und Minderheitenschutz bei börsennotierten Kapitalgesellschaften, Working paper, University of Würzburg.

Wenger, E. and C. Kaserer, 1997, German banks and corporate governance: A critical view, Working Paper, University of Würzburg. 